\title{
SPATIAL DIFFUSION AND THE FORMATION OF A TECHNOLOGICAL INNOVATION SYSTEM IN THE RECEIVING COUNTRY: THE CASE OF WIND ENERGY IN PORTUGAL
}

\begin{abstract}
This paper investigates how energy technologies diffuse spatially through the examination of wind growth in Denmark (core) and Portugal (follower). The research draws on the empirical historical scaling dynamics to compare patterns of diffusion, and proposes an explanation for these patterns with the help of the technological innovation systems (TIS) theoretical framework. The analysis uncovered an acceleration of diffusion when the technology attained the new market. The mechanisms that allowed rapid adoption were found to be, among others, transnational linkages and an improved absorptive capacity. The latter benefited from past investments in knowledge development, imports of state-of-theart technology and construction of a local industry assembling available competencies. Targeted policies (e.g. tender-based feed-in scheme) were effective to stimulate technology transfer and boost diffusion. The linkages with the global TIS and the concept of absorptive capacity improve the understanding of the processes involved in the formation of a TIS in receiving countries.
\end{abstract}

Keywords: technological innovation systems; spatial diffusion; absorptive capacity; wind energy.

JEL Classification: L2; O33; O38; Q42; Q55; R11. 


\section{Introduction}

The diffusion of low carbon technologies across regions is essential to tackle climate change in the years to come (IPCC, 2014). In the last decade, the electricity sector has witnessed a spectacular investment increase in renewable energy sources, especially wind energy. The global cumulative installed capacity of wind power has reached $282 \mathrm{GW}$ in 2012 (GWEC, 2013), generating $521 \mathrm{TWh}$, or $2.3 \%$ of total gross electricity consumption (BP, 2013). Even though China leads in terms of installed capacity (around $70 \mathrm{GW}$ ), the majority of wind plants are still located in OECD countries.

The objective of this paper is to contribute to our understanding of the process of spatial diffusion of wind energy technologies and how it can lead to the development of more sustainable energy systems. It addresses a case of diffusion from a pioneer country (Denmark) to a fast follower one (Portugal), comparing the development of wind energy in both countries and analyzing the processes that enabled fast technology development and the building-up of a wind energy system in the latter. Denmark clearly assumed the leading role in technology developments in the 1990s (see Garud and Karnøe, 2003; Karnøe and Garud, 2012; Bergek and Jacobsson, 2003; Kamp et al., 2004; Neij and Andersen, 2012), especially after the unsuccessful commercialization of early multi-megawatt wind power plants in the previous decade in the US and Germany (Gipe, 1995). A variety of knowledge and technological exchanges took place between Portugal and Denmark since the early stages (even if other countries like Germany also became suppliers of technology and know-how later in the process).

Portugal is an interesting case of study, not only given the speed of wind energy penetration but also for the modes it assumed. On the one hand, wind energy registered a remarkable growth in the past decade, becoming the second most important renewable energy source after hydropower. In 2011, it produced $17.2 \%$ of total electricity consumption, the second highest share among OECD countries, only surpassed by Denmark (EWEA, 2013; DGEG, 2013). On the other hand, the application of a mix of demand "pull" and supply "push" policies resulted in the formation of an industrial cluster and ultimately in a national incorporation of inputs that reached $100 \%$ (with exports representing more than $60 \%$ of production, cf. Público, 2011). This case reasserts the conclusions of previous studies that pointed to the role of home markets for industry expansion in renewable energy technologies (Lund, 2009; McDowall et al., 2013). Yet, there is still limited knowledge about the process of emergence and development of wind energy in Portugal, which may offer some lessons on the factors that can lead to rapid diffusion of renewable energy technologies in follower countries.

In order to conduct this analysis, the paper draws on the literature that addresses the emergence and growth of new energy technologies, in particular recent conceptualizations that give an increasing attention to the spatial dimension of these processes. It makes use of contributions from historical scaling dynamics analysis (Wilson 2009; Grubler, 2012) to reveal patterns that are then discussed with the help of theories and concepts from the technological innovation systems literature (Bergek et al., 2008a; Hekkert et al., 2007, 2011). 

analysis (Wilson, 2012, 2009; Grubler, 2012), which found strong patterns of market growth in and across regions. This approach centers on the analysis on technology scaling, i.e. technological growth that is both rapid and extensive and occurs at multiple levels: the technology unit size and the industry as a whole (Wilson, 2012). One important contribution of the historical analysis concerns the patterns of international diffusion: it uncovered an acceleration of growth rates when energy technologies move from the initial markets and start diffusing in new regions, i.e. diffusion is faster in subsequent markets (see Grubler, 2012, 1998).

The Technological Innovation Systems (TIS) literature addresses the emergence of new technologies from a systemic perspective, as a process of formation and development of a new innovation system. In contrast with the previous approach, more centered on the technology, it investigates the evolution of the structure in terms of actors, networks and institutions, as the technology evolves over time (Carlsson and Stankiewicz, 1991; Bergek et al. 2008a; Jacobsson and Bergek, 2012). More recent theoretical developments added the notion of core processes or functions of the innovation system that are decisive for the performance of the emerging TIS (Bergek et al. 2008a; Hekkert et al., 2007). Thus the TIS provides a more encompassing framework that permits to explain the empirical patterns identified by the historical scaling analysis, offering the theoretical instruments to understand the processes that underlay the development, diffusion and use of innovations.

One of the advantages of the TIS theoretical framework is that it views technology emergence and growth as a global process that transcends sectoral and geographical boundaries (Carlsson and Stankiewicz, 1991; Bergek et al, 2008). However the majority of empirical studies tends to concentrate on the national level, overlooking the interactions between different regions (Markard et al., 2012; Coenen et al., 2012). That is, they tend to ignore that the formation of a TIS in a given country receives extensive external influences. In this paper, the TIS approach is mobilized in the perspective of Markard and Truffer (2008), considering the local innovation system as part of a global TIS, which influences its formation and growth.

The paper extends the very recent empirical research on the treatment of space in the TIS (Binz et al., 2014, 2012; Vasseur et al., 2013), by looking at the process of diffusion as it unfolds when the technology reaches enough maturity to spill over from the initial markets and start moving into new regions. Furthermore, it examines the relationships between the different regions along this process, and investigates how the performance of system functions in the "receiving" region influences the process of diffusion. This analysis offers new insights on how transnational interactions can contribute to accelerate the formation of a local TIS, enabling the country to rapidly seize the opportunity to participate in a growing market (Lee, 2009; Markides and Geroski, 2005).

The empirical research centers on the spatial diffusion of wind energy technologies, analyzing the development of wind energy in Portugal and comparing it with that of Denmark, in order to answer the following questions: How do energy technologies such as wind power evolve spatially? Which processes take place, as part of the formation of a TIS, that enable a country to bring about rapid transfer of the technology and become a fast follower?

The paper is organized as follows. Firstly, the conceptual framework is presented. Secondly, the methodology and data sources are explained. Thirdly, the spatial diffusion of wind energy from a core 
country - Denmark - to a fast follower country like Portugal is examined, by analyzing diffusion dynamics and the mechanisms involved in the process. ${ }^{1}$ The understanding of the determinants of spatial growth of wind power to a fast adopter country will allow a better design of strategies that can be used to promote the widespread adoption of low carbon technologies.

\section{Emergence of new energy technologies and spatial diffusion}

Two approaches have recently appeared in the literature that aims to understand the process of emergence and growth of new technology systems. The first is the technological innovation system (Bergek et al., 2008a; Hekkert et al., 2007, 2011) that comes from the more theoretical field of socio-technical transitions (Markard et al., 2012). The second is the recent historical scaling dynamics analysis (Wilson, 2012, 2009) which comes from the tradition of applied systems analysis (Grubler, 2012, 1998).

\subsection{Technological innovation systems}

\subsubsection{Conceptual model: Structural and functional dimensions}

The model of Technological of Innovation Systems (TIS) focuses on the emergence of novel technologies and the institutional and organizational changes that are needed for the formation and growth of the new technology system (Markard et al., 2012). Innovation is understood as an interactive process involving a network of actors (e.g., firms, users), who act within a particular context of institutions and policies that influence technology development, adoption behavior and performance, and who bring new products, processes and organization structures into economic use (Carlsson and Stankiewicz, 1991; Bergek et al. 2008a; Jacobsson and Bergek, 2012). This definition highlights the three main elements constituting the structure of the new technology system (Bergek et al., 2008a; Jacobsson and Bergek, 2004): actors, networks and institutions. Actors include firms and other organizations (e.g. universities, industry associations) along the value chain (Bergek et al., 2008a). Networks are the result of links established between fragmented components to perform a particular task (e.g., learning and knowledge creation and diffusion, standardization and market formation, political and advocacy coalitions). Institutions consist of formal rules (e.g., laws and property rights) and informal norms (e.g. tradition and culture) that structure political, economic and social interactions (North, 1990). Institutions have three roles in innovation systems (Edquist and Johnson, 1997): to reduce uncertainty by providing information; to manage conflicts and promote cooperation; and to provide incentives for innovation.

In addition to the structural view presented above, this approach also considers the evolution of the functional dimension of the innovation system (Hekkert et al., 2007; Markard et al., 2012). The literature

\footnotetext{
${ }^{1}$ In this paper, terms such as core, center and pioneer, are used as synonymous for markets of first commercialization; whereas (fast) followers refer to the countries that adopt the new technology after the former group. The latter countries are normally (but not exclusively) found among OECD countries other than G7, intermediate economies, or even economies in process of catching up with developed ones.
} 
on TIS focuses on a set of processes, or functions, that are required for the innovation system to start, grow and gain momentum. ${ }^{2}$ Bergek et al. (2008b) identified eight key functions of innovation systems that support the development, dissemination and use of a new technology. ${ }^{3}$

Development of formal knowledge concerns the way knowledge is developed, diffused and combined in the system, in order to create a knowledge base. Entrepreneurial activities relate to the development of a more applied, tacit and explorative knowledge, through the conduction of technical experiments or testing of new markets and applications. Materialization refers to the investment in artifacts such as products, factories and physical infrastructures. Influence on the direction of search refers to the capacity to attract new supply-side actors and to direct their search and investments towards the TIS. Market formation involves the articulation of demand around increasingly organized markets, from demonstration projects to niche markets and, if successful, to large-scale diffusion. Resource mobilization refers to how the TIS is capable of attracting human capital, financial capital and other complementary assets from other sectors. Legitimation comprises the process of formation of expectations and visions (including the action of advocacy coalitions) as well as alignment of regulation through mechanisms such as market regulations, economics instruments or science and technology policy. Development of positive externalities provides insights about the strength of the collective dimension of the TIS, and the dynamics of the system in terms of the extent to which the other functions contribute to the generation of positive externalities.

Previous research on the formation of energy technology innovation systems (e.g., wind, solar, biomass) has called the attention to three important features of change. Firstly, a small number of functions emerged as particularly relevant for sparking system dynamics: "legitimacy", "influence on the direction of search" and "market formation" (Hekkert and Negro, 2009; Hekkert et al, 2007). It is argued that the first helps to align institutions to the needs of agents and technologies, whereas the second and the third are important for raising entrepreneurial activities. Secondly, key system functions are likely to change over time, with knowledge development and direction of search being crucial in the earliest formative period, whereas market formation become important in a more advanced stage of TIS formation (Bergek et al., 2008a). Thirdly, interactions between functions - also called 'motors' of innovation (Suurs and Hekkert, 2009) may lead to "virtuous cycles" that accelerate system emergence and growth (Hekkert and Negro, 2009). This is likely to happen later in the formative phase, when more functions are fulfilled, leading to stronger internal dynamics and to system growth.

\subsubsection{Spatial dimension}

The TIS approach has the advantage of moving beyond sectoral and geographical boundaries to analyze how a technology develops, diffuses and is used (Hekkert et al., 2007 Bergek et al., 2008a). This means that the process of construction of a TIS at country level can be conceptualized as part of a larger, 'global' TIS development (Markard and Truffer, 2008). However, most empirical studies have tended to

\footnotetext{
${ }^{2}$ Bergek et al. (2008a) distinguish between a formative phase and a growth phase. The formative phase is when "... constituent elements of the new TIS begin to be put into place, involving entry of some firms and other organizations, the beginning of an institutional alignment and formation of networks." (p. 419), while in the growth phase "... the focus shifts to system expansion and large-scale technology diffusion through the formation of bridging markets and subsequently mass markets..." (p. 420).

${ }^{3}$ Researchers at Utrecht University have developed an alternative list of innovation functions that is relatively close to the one used in this paper (see Hekkert et al., 2007).
} 


\subsection{Patterns and drivers of the historical growth of energy technologies}

A more empirical literature, which comes from the tradition of diffusion of innovations and system analysis (Rogers, 1995; Grubler, 2012, 1998), analyzed the historical diffusion of several energy technologies, focusing on the effect of scaling to draw lessons about technology development (Wilson 2012; Wilson and Grubler, 2011). Scaling refers to the growth that is both rapid and extensive, as well as occurs at multiple levels of individual technologies (increases of unit scale like larger turbines) and of entire industries (industry scale) (Wilson, 2012). The substantial cost reductions permitted by economies of scale following technology scaling-up further drives the dynamics of energy transition. This methodology enables the analysis of patterns of diffusion over time and spatially, through the study of technology scaling.

The importance of scaling in the past diffusion of technologies has been widely demonstrated in Wilson (2012, 2009) and Wilson and Grubler (2011). Firstly, it has been shown that the speed of diffusion is influenced by market size, so that innovations with a higher potential should take longer to diffuse. Secondly, previous analyzes of several energy technologies have revealed that growth typically evolves in a three-phase sequential process (cf. Wilson, 2012): formative phase, unit scaling and growth phase. The formative phase is normally a long period of experimentation and learning with small unit-scale technologies but a diversity of designs and producers. The technology improves over the period in terms 

that became standard(s). The up-scaling phase (in case scaling is technologically feasible) is characterized by the rapid increase of the size of individual technologies in order to significantly lower costs by the effect of economies of scale, until the gains saturate as the technology approaches the scale frontier. Finally, the technology enters into a period of industry growth and globalization, when there is an increase in the sales of large unit-scale technologies in the first markets. The growth of the industry allows further cost reductions through economies of scale in manufacturing, leading to consolidation and concentration of production in larger firms that have cost advantages. When the first signs of market saturation in the innovation core appear, further industry growth is driven by diffusion in other regions.

Thirdly, the analysis of international patterns of diffusion pointed to an acceleration of growth rates as innovation penetrates into new areas (Wilson, 2012; Grubler, 1998; Bento, 2013). In other words, the rhythm of penetration becomes faster as the new technology transits from initial to subsequent markets the diffusion in new regions enlarges the market potential and improves the technology attractiveness by continually reducing costs and improving performances, but typically saturates more rapidly requiring the expansion to the next, more peripheral areas, before the technology reaches global saturation. ${ }^{4}$

The fact that new technologies (get out from the core and) start diffusing abroad when they become sufficiently mature may explain why adoption is faster in the subsequent markets, as they benefit from the learning investments previously made by the lead countries in $R \& D$ and in early deployment of the technology (Perkins and Neumayer, 2005; Nemet, 2009). Indeed, other regions take advantage of the knowledge and technology spillovers created during the previous diffusion in the core (Jaffe, 2005). The literature of international diffusion and economic catching-up shows that the typical channels for international technology transfer after the post-war have been capital imports, foreign direct investment (FDI) and licensing (Mowery and Oxley, 1995; Mowery et al., 1996; Keller, 2010). Keller (2010) emphasizes the role of international trade and FDI in the capture of technology spillovers. In this perspective, the local capacity to exploit these externalities can be enhanced by importing technology or with the physical presence of international companies.

However, international technology diffusion is not automatic from the existence of a knowledge base in the core, but requires the recipient to have the capacity to absorb and assimilate such technology in order to take the maximum benefit from it (Mowery and Oxley, 1995; Teixeira and Fortuna, 2010). The term "absorptive capacity" was coined by Cohen and Levinthal $(1989,1990)$ in order to designate the ability of organizations (and ultimately their countries) to exploit external knowledge. ${ }^{5}$ At the macro level,

\footnotetext{
${ }^{4}$ A similar conceptualization of innovation growth by phases was suggested by Bergek and Jacobsson (2003) in their study of the emergence and growth of the wind innovation system in Germany, Sweden and The Netherlands: "The first [stage] is characterised by substantial technological variety (and uncertainty), underdevelopment of the market and entry of many firms. The second is characterised by a considerable turbulence, driven by rapid growth in the market and an up-scaling of the turbines (corresponding to a set of minor technological discontinuities), as well as by many exits but also some new entrants, including some larger firms. [...] we will therefore distinguish between a phase of experimentation (roughly 1975-1989) and one of turbulence and growth (roughly 1990-1999)."

${ }^{5}$ The authors point out that "...while R\&D obviously generates innovations, it also develops the firm's ability to identify, assimilate, and exploit knowledge from the environment..." (Cohen and Levinthal, 1989, p.565). See Todorova and Durisin (2007) and Zahra and George (2002) for more refined models of firms' absorptive capacity comprising recognition of the value,
} 
acquisition, transformation/assimilation, and exploitation of external knowledge and Narula (2004) and Criscuolo and Narula (2008) for an attempt to extend the concept to the national and "innovation system" level. Empirical studies are surveyed in Lane et al. (2006), Volberda et al. (2010) and Ebers and Maurer (2014).

${ }^{6}$ Indeed the experience of transfer of wind technology to California in the 1980s (Kamp et al., 2004) has shown that the level of maturity of the technology is not enough to drive a successful energy transition in the local market. We thank an anonymous review for highlighting this point.

The above discussion suggests that a more "spatialized" technological innovation systems perspective can provide an appropriate conceptual framework to address and explain the patterns uncovered by the historical analysis of diffusion. The TIS approach permits to move beyond an explanation for the acceleration of diffusion largely focused on the stage of development of the technology ${ }^{6}$, to one that centers on an understanding of the core activities that allow the rapid construction of a successful innovation system in the receiving country. That is, the TIS approach permits to uncover the mechanisms that intervene in the adoption of a new technology by the follower and in the building up of a local innovation system.

\section{Methodological issues}

This research aims to analyze patterns of spatial diffusion and explaining them with the help of concepts issued from the technological innovation systems literature (Markard et al., 2012; Bergek et al., 2008a; Hekkert et al., 2007, 2011). Instead of studying the strategies pursued in core countries only (e.g. Garud and Karnøe, 2003; Kamp et al., 2004; Hendry and Harborne, 2011; McDowall et al., 2013), our analysis examines the conditions under which rapid transfer of technology is possible from the core to other regions. 
The paper compares the case of wind development in two countries: Denmark (representing the "core" of the innovation) and Portugal (a "fast follower" country). The comparison of the dynamics of growth of wind energy in these two countries may reveal historical patterns, providing a ground for a discussion on the possible determinants of spatial technological diffusion.

The diffusion analysis applies the historical scaling methodology developed in Wilson (2009) and Wilson and Grubler (2011). Logistic growth models are used to fit actual numbers - either in turbine size and in installed capacity - and to (eventually) distillate historical patterns in the growth of wind power (Grubler, 1998, 2012; Marchetti and Nakicenovic, 1979). These functions estimate key parameters of diffusion that can be compared across countries: saturation level $(\mathrm{K})$; the inflection point $\left(\mathrm{t}_{0}\right.$ coinciding with the point of maximum growth, i.e. F50\%); and the duration of growth ( $\Delta \mathrm{t}$ referring to the time length between $\mathrm{F} 10 \%$ and $\mathrm{F} 50 \%$ ).

Drawing on this evidence, the paper uses the TIS framework to investigate the processes at work over time, in order to provide an explanatory account of the fast development of installed capacity in the follower country. First, the formation of the structural components of the wind TIS in Portugal is examined in terms of the evolution of the configuration of actors, networks and institutions over time. Second, the fulfillment of key processes is mapped through the identification of main events and their organization around system functions. Particular emphasis is put on the processes that enabled the identification, acquisition, assimilation and transformation of external technology, i.e. promoted (domestic) absorptive capacity.

For this purpose the paper uses the set of system functions elaborated by Bergek et al. (2008b), which is expanded to comprise international aspects (Binz et al, 2012), and allocates specific activities to each function, using a number of indicators, as suggested by Vasseur et al (2013). Table 1 presents the functions and respective indicators, distinguishing between processes taking place mostly at national level and those that result from transnational linkages with the global TIS (Gosens et al, 2013). The definition of the national indicators builds on Gosens et al (2013) "domestic system activities", adapting them to the Portuguese wind energy system. This includes activities that contribute to increase the country's capacity to identify, absorb and transform knowledge or technology obtained through international flows. For instance, development of human capital and local R\&D efforts are allocated to resource mobilization and development of formal knowledge, respectively, as part of the country level activities. In order to introduce the international dimension, transnational linkages (e.g. trade in equipment, foreign direct investment, international joint ventures, international research cooperation, and participation in international scientific conferences, see Binz et al, 2012) are transformed into indicators, which are allocated to the relevant system functions (Vasseur et al., 2013; Gosens et al., 2013), as shown in Table 1. For instance: international research collaboration is an indicator for formal knowledge development; the selection of foreign technologies that better fits domestic needs provides direction of search; strategies of international manufacturers for the domestic industry, which lead to foreign direct investment or joint ventures with local companies, are an indicator of materialization; private foreign investment or access to European funds are indicators of resource mobilization. 
International linkage indicators

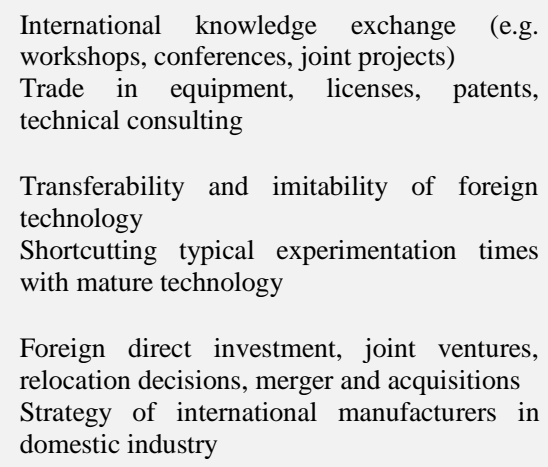
technology

Shortcutting typical experimentation times with mature technology

Foreign direct investment, joint ventures, relocation decisions, merger and acquisitions Strategy of international manufacturers in domestic industry

F3. Materialization New factories opened by domestic firms

F4. Influence on the direction of search

F5. Market formation

F6. Resource mobilization

F7. Legitimation

F8. Development of positive externalities
Perspectives of profits in the future for the new technology vs conventional

New entrants in the market

Unit numbers, installed capacity

Financial capital, human capital, complementary assets

Recognition of societal benefits of the technology Formation of advocacy coalitions and lobbying activities

Direction of science and technology policy

Regulatory and fiscal instruments (e.g. FIT)

Cost reductions

Strength of political networks
Selection of foreign technologies that better fits domestic needs

Degree of preference for foreign or domestic manufacture

Share of domestic and foreign companies in the market

Foreign direct investment, venture capital, international banking sector

Access to European funds

Domestic policy vs international trade regimes (WTO, EU)

International technology growth and legitimation

Improvements in foreign technology's performance and costs

This framework is applied to the analysis of the process of formation and maturation of the wind energy system in Portugal, drawing on qualitative and quantitative data collected from a variety of documentary sources (e.g., official statistics, policy documents, newspapers and specialized magazines, industry documents). In addition, key actors of the wind and energy sector in Portugal, from industry (e.g. equipment manufacturers, developers, electricity producers), academia and government agencies were interviewed. The information thus obtained permits to trace the evolution of the structure of the innovation system, identifying main events and key actors.

The main sources of data for the time series (e.g. on installed capacity, wind electricity production, investment costs) were official statistics published by organizations such as International Energy Agency (IEA), Danish Energy Agency, Portuguese National Institute of Statistics, Portuguese Directorate-General for Energy and Geology (DGEG), and Global Wind Energy Council (GWEC). 


\section{Spatial diffusion of modern wind energy: The case of Portugal}

\subsection{The diffusion of wind power in a fast follower context}

This section examines the growth of wind technologies in a rapid second adopter country: Portugal. The country's involvement in renewable energies was triggered by the signature of the Kyoto Protocol and the subsequent "Renewables Directive" (2001/77/CE, 27 September) which established, for Portugal, the target of 39\% for electricity produced from renewable energy sources in gross electricity consumption by 2010. In 2001, the government approves the E4 Program (Energy Efficiency and Endogenous Energies) aiming to double the installed capacity of endogenous energies, in a horizon of 10 to 15 years. This included the installation of 2,500 to 3,000 MW of wind capacity by 2010 . Wind was chosen since, by the time, it was much more advanced and cheaper than alternative renewable technologies, such as solar photovoltaics (Castro, 2011). To achieve that goal, the government introduced a very attractive remuneration for renewable sources and simplified the administrative procedures for the connection of new capacity.

The diffusion of wind power in Portugal was rapid and impressive, as most of the wind turbines were deployed after 2000. The growth in wind capacity kicks off in 1999, when it was as low as $58 \mathrm{MW}$, doubling in average every other year. The installed capacity reached 4,364 MW (21\% of total capacity) in 2011 (DGEG, 2013). As a result, the part of wind in total electricity consumption has been increasing to reach 18\% in 2012 (DGEG, 2013). This is the second highest in Europe (only surpassed by Denmark), and was decisive to raise the share of renewable energies in final electricity consumption from $21.1 \%$ in 1999 to $45.3 \%$ in 2011, which is also one of the highest in Europe (Figure 1). 
Figure 1. Shares and targets of renewable electricity and wind power in gross final electricity consumption in top wind countries in the $\mathbf{E U}$

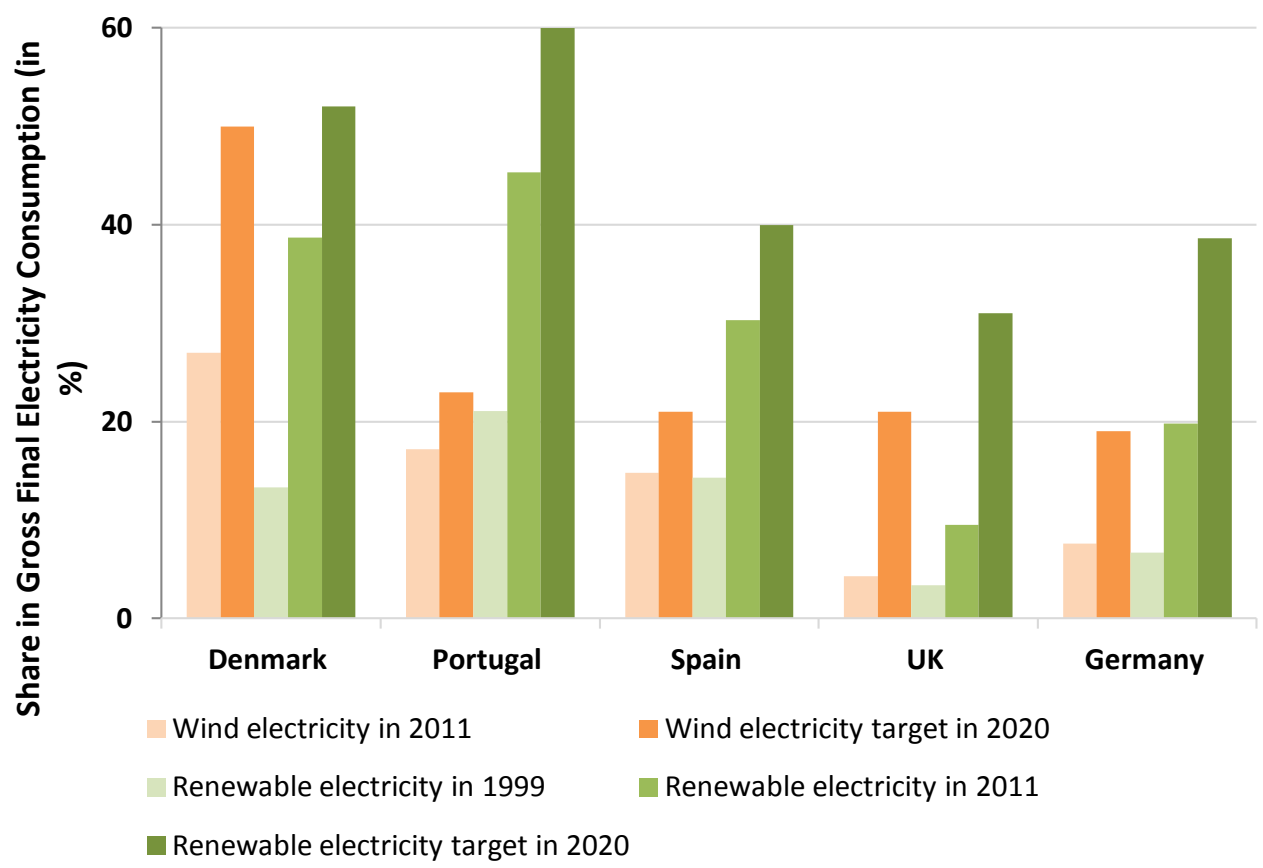

Sources: DGEG (2013, p.12); National Renewable Energy Action Plans (NREAPs) of the European Member States: Beurskens et al. (2013, Table 3 and 10a/b); Ren21 Map <http://map.ren21.net> (accessed in September 17, 2013); Plano Nacional de Acção para as Energias Renováveis (PNAER in Resolução do Conselho de Ministros n 20/2013, 10 April).

The comparison of the patterns of wind power growth in Portugal and in Denmark (representing the "core") is presented in Figure 2. The raise in total installed capacity takes off in the former when diffusion was well advanced in the latter (i.e. around $40 \%$ of saturation). However, the speed of deployment accelerates when the technology enters into the Portuguese market. The adoption lag can be measured by the difference in the inflection points $(\mathrm{F}=50 \%$ coinciding with the year of maximum growth) of the logistic curves fitting actual growth in the two countries. In these terms, the delay of adoption from Denmark (core) to Portugal was only 7 years, which is very fast comparing to the spatial diffusion of other energy technologies in developed countries in the past (Grubler, 2012; Bento and Fontes, 2013a). Furthermore, the diffusion took 8 years in Portugal, whereas it had taken 14 years in Denmark (see differences in $\Delta t$ ). The reasons for a faster growth in the receiving country are analyzed more in detail in the following sections.

More than $500 \mathrm{MW}$ of wind power were installed annually in Portugal in the period between 2004 and 2009. At the same time, wind turbine prices were raising everywhere (Figure 3), in spite of the declining cost trajectories predicted by the learning curve theory and observed in the previous decades (Grubler et al., 2012). This reflected a general movement at international level, due to the joint effect of a surge in demand for wind turbines and the raise of production costs motivated by increasing labor and materials prices and profit margins (Bolinger and Wiser, 2012). Still, the increase in the remuneration of electricity 
generated from wind in Portugal more than compensated the rise in costs, guaranteeing the profitability of wind farms.

Figure 2. Historical evolution of total cumulative installed capacity of wind power in Portugal and Denmark (1977-2012), indexed to the estimated saturation $(K=1.00)$

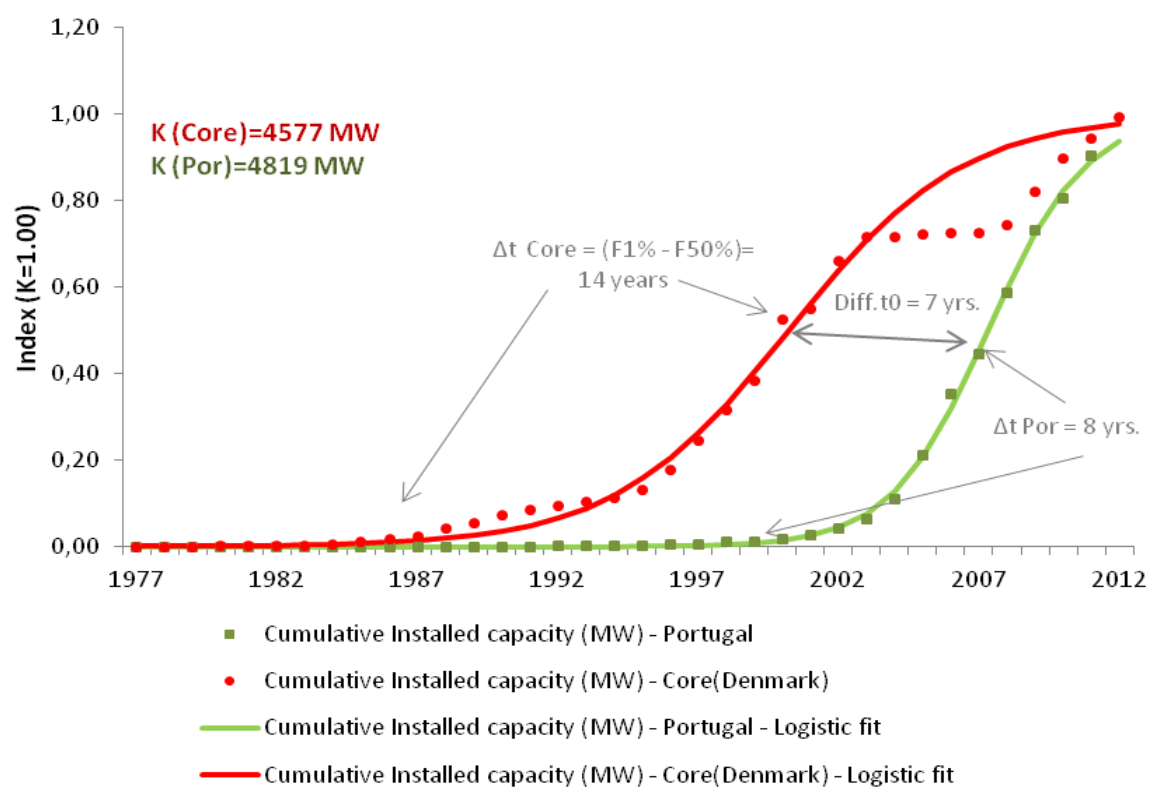

Source: DGEG, 2013; Spliid, 2013.

Figure 3. Evolution of average wind turbines costs and tariffs for wind power in Portugal between 1998 and 2011

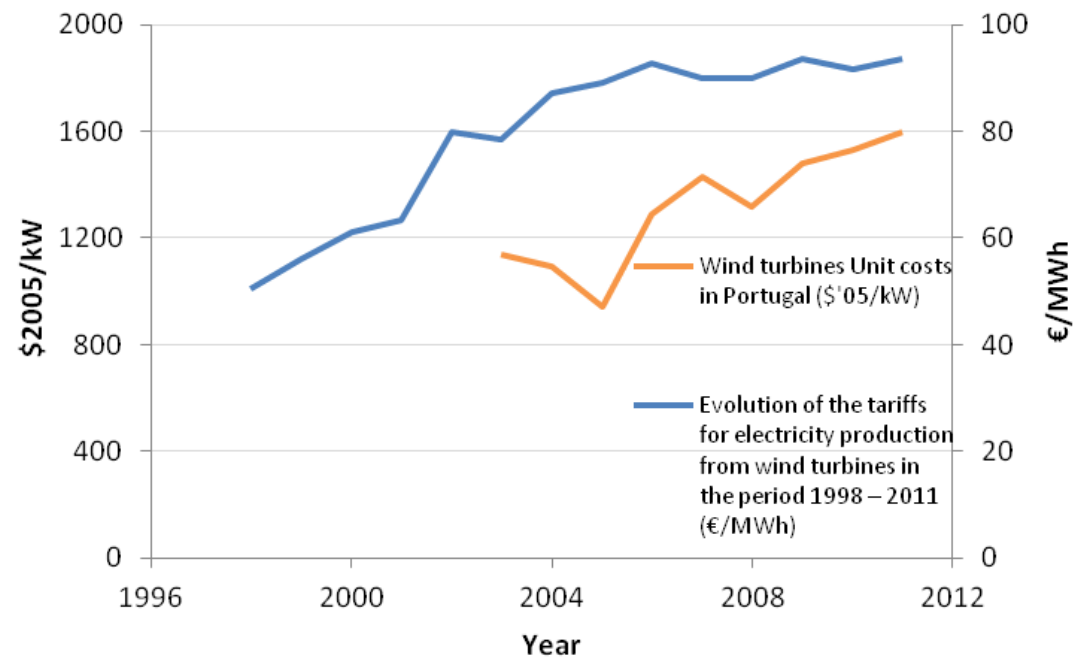

Sources: IEA $(2012,2009,2003)$. 


\subsection{Comparative analysis of spatial patterns of diffusion}

A new technology typically progresses in the core and spills over when it is competitive enough to start diffusing in other regions. The moment when the technology leaves the core (before or after up-scaling) is investigated below, for the case of wind power. Yet the implementation of units of a larger size in the subsequent markets always requires the availability of local resources (e.g. human, financial, knowledge). The speed of scaling is therefore an indicator of the rhythm of absorption, diffusion and use of the innovation in these new markets, whose emergence can be explained with the TIS literature.

The dynamics of growth of wind power in Denmark and Portugal are compared in Figure 4. In this case, the follower country adopts the new technology after its up-scaling in the core. In fact, Danish manufacturers were already commercializing $3 \mathrm{MW}$ wind turbines by the end of the 1990s. The new models had significantly improved their efficiency and performances, registering important reductions in the average downtime rates (to less than 2\%) and turbine noise (Neij and Andersen, 2012). At the same time, investment costs in wind turbines were cut by half between 1980 and 2000 (op. cit). Moreover, the results confirm that the sequencing of unit and industry scaling is faster in the follower country (PT) than in the core (DK). Comparing the three-stages of growth in the two countries permits to conclude that: the "formative phase" is much longer in the core than in the follower, because of the need of experimenting with more units in the former; the "unit scaling" is much more rapid in the follower, which shows a faster growth in the size of average and maximum unit additions; and, finally, the "growth phase" reaches saturation more rapidly in the follower (steeper slope of the light blue curve) than in the core. In all, the steeper curves in the case of Portugal indicate the acceleration of growth once wind power leaves Denmark, i.e. the core market. 
Figure 4. Unit and industry scaling: known data (dots) and logistic fits (lines) indexed to $K=1.00$
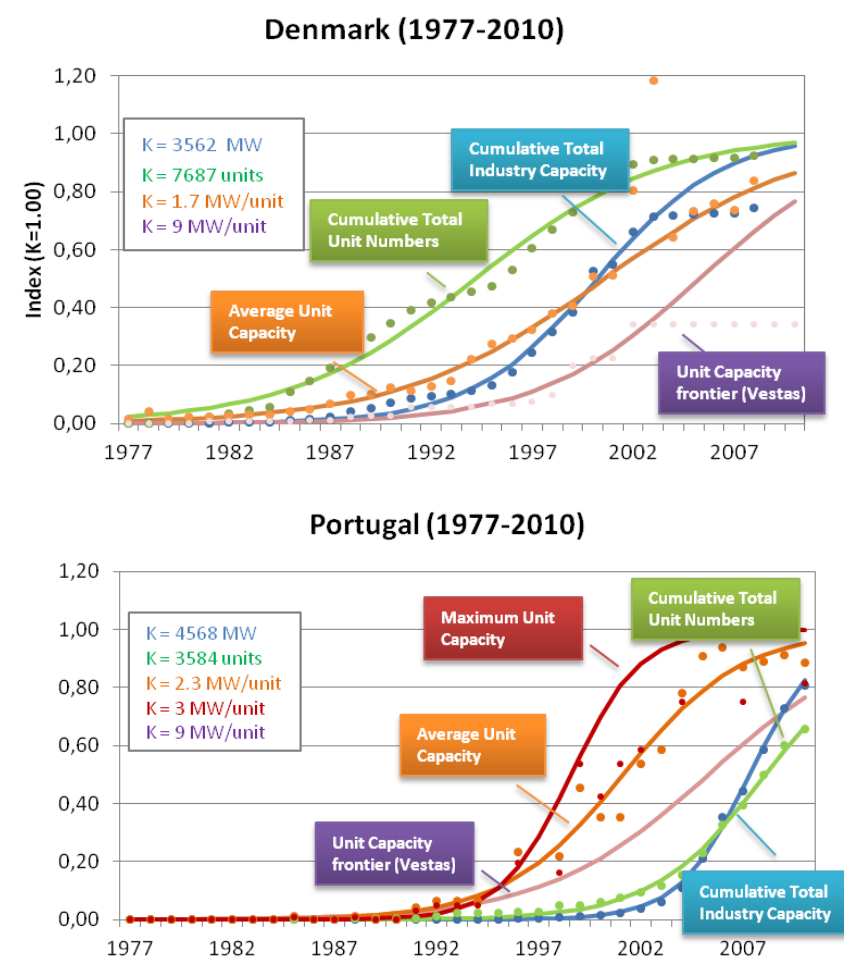

Source: DGEG, 2013; Spliid, 2013.

A more detailed analysis of turbine scaling and growth of wind electricity production in the two countries gives further information about the spatial diffusion of wind power (Figure 5). The top graph compares the evolution of average and maximum (or capacity frontier for DK) unit additions in the core (DK) and in Portugal. The graph reveals that growth was again much more rapid (i.e. steeper curves) in the second than in the first, showing clearer the acceleration of unit scaling in the next market. According to the historical scaling dynamics approach, the diffusion of larger size turbines was quicker in the follower mainly because much of the technical problems had been previously solved in the core and due to the existence of knowledge spillovers - we come back to this in the next point. 
Figure 5. Comparing unit scaling (top) and the share of wind in the electricity mix (bottom) in Denmark and Portugal, logistic fits only

Spatial acceleration (Unit scaling): Denmark vs Portugal

Logistic fits indexed to $K=1.00$

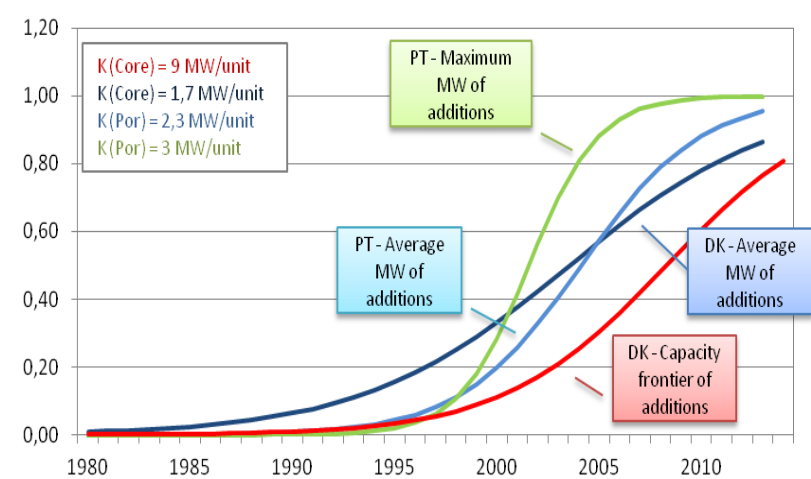

Spatial acceleration (Elec.Generation): Denmark vs Portugal, Log fits indexed to $K=1.00$

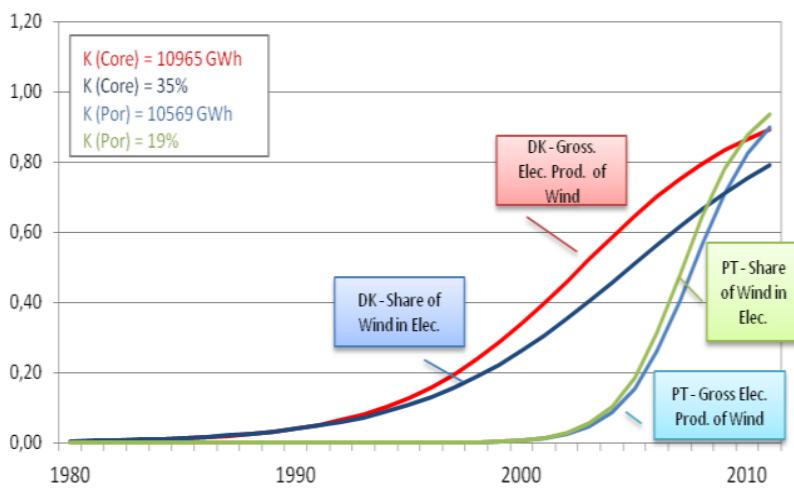

Source: DGEG, 2013; Danish Energy Agency, 2013.

The second graph (Figure 5, bottom) shows how quickly capacity growth translates into higher electricity production. The figure presents the increase in gross electricity production from wind (in GWh), as well as the progress of its share in the overall electricity mix. Both indicators follow a close path, particularly in Portugal. In this case, wind production takes off well within the $2000 \mathrm{~s}$ - with a great delay when compared with its beginning in the late 1980s in Denmark - a few years later than unit scaling. Its evolution is particularly fast when compared with the trend of average unit additions (i.e. a growth rate or " $\Delta \mathrm{T}$ " of 13 years vs. 6 years for the increase of the share of wind in electricity production). Nevertheless, the share of wind power in the electricity-mix is larger in Denmark: it is currently $28 \%$ and can potentially reach $35 \%$, if the present trend is followed in the coming years. These figures compare to 18\% and 19\%, respectively, for Portugal. Still, the growth potential falls short of the 2020 target in both countries (i.e. $50 \%$ for Denmark and 23\% for Portugal).

All in all, the evidence surveyed from wind development in Denmark and Portugal points to an acceleration of diffusion when this technology spills over from the core to reach new markets. The data 


\subsection{The process of creation of a new technological innovation system in the receiving country}

This section analyzes the processes that contributed to the spatial diffusion of wind power at local level, particularly through the establishment of the structural components, the fulfillment of the functions of the innovation system (e.g. knowledge creation, entrepreneurial experimentation), and the interactions established between them, as the new technological innovation system emerges and grows. ${ }^{7}$

The wind TIS in Portugal has involved a growing number of actors. The former national utility EDP was the first developer of modern wind farms and remains the largest producer of wind electricity. The company also plays a key role in the consortium ENEOP, which is the main domestic equipment supplier. ENEOP was established as a joint venture between wind farm promoters (EDP, Endesa, and GDF-Suez) and an industrial partner (Enercon), following the public tender in 2006 for building, installing and operating 1,200 MW. It also includes several small and medium local companies. In 2012 the wind industry provided 2,700 direct and indirect jobs, with EUR 0.5 billion turnover and more than $60 \%$ of exports (EurObserv'ER, 2013, Publico, 2011). These figures comprise manufacturing of turbines, installation, operation and maintenance of wind farms. Wind research is well established in Portugal, with some organizations - e.g. LNEG and research groups based at Faculty of Engineering of Porto University (INEGI, INESC) - working in the field since the 1980s and being active in international projects (IEA, 2004). The national energy policy is traditionally managed by the Secretary of State for Energy (under the Ministry of Economic Affairs and later the Ministry of Environment, Spatial Planning and Energy). In what concerns networks, the association of renewable energy actors (APREN), formed in the late 1980s, is the main advocacy coalition that lobbies the government and had an important role in the establishment of the incentive schemes for wind energy. Learning networks are composed of research institutes, universities and institutes involved in R\&D projects financed through national and European grants. These organizations also collaborate with energy companies and equipment manufacturers in specific pilot projects. Finally, the institutions were decisive for the growth of the home market: there was a stable policy and consistent regulatory regimes for wind (IRENA-GWEC, 2012; Peña, 2013). The targets for wind are established in the national plan for renewable energies (PNAER). However, the recent economic crisis led to a revision of the goal for the installed capacity of wind power by 2020, which decreased from 6,875 MW in the 2010 version to 5,300 MW in the 2013 revision.

\footnotetext{
${ }^{7}$ A more detailed analysis of the process of formation and growth of wind power in Portugal can be found in a separate paper: Bento and Fontes (2013b).
} 
It is possible to distinguish two distinct periods in the development of wind power in Portugal: the exploratory and formative stage; and the implementation stage. The former begins with exploratory activities in the 1980s and goes on until the installation of the first wind farm, whereas the latter comprises the up-scaling phase of turbines between 1996 and 2003 and the capacity growth that followed. The processes taking place along each stage are depicted in Figures 6 and 7, where a full arrow indicates a direct relation; and a dotted arrow indicates indirect flows.

\section{Figure 6. Exploratory and formative stage of wind energy in Portugal}

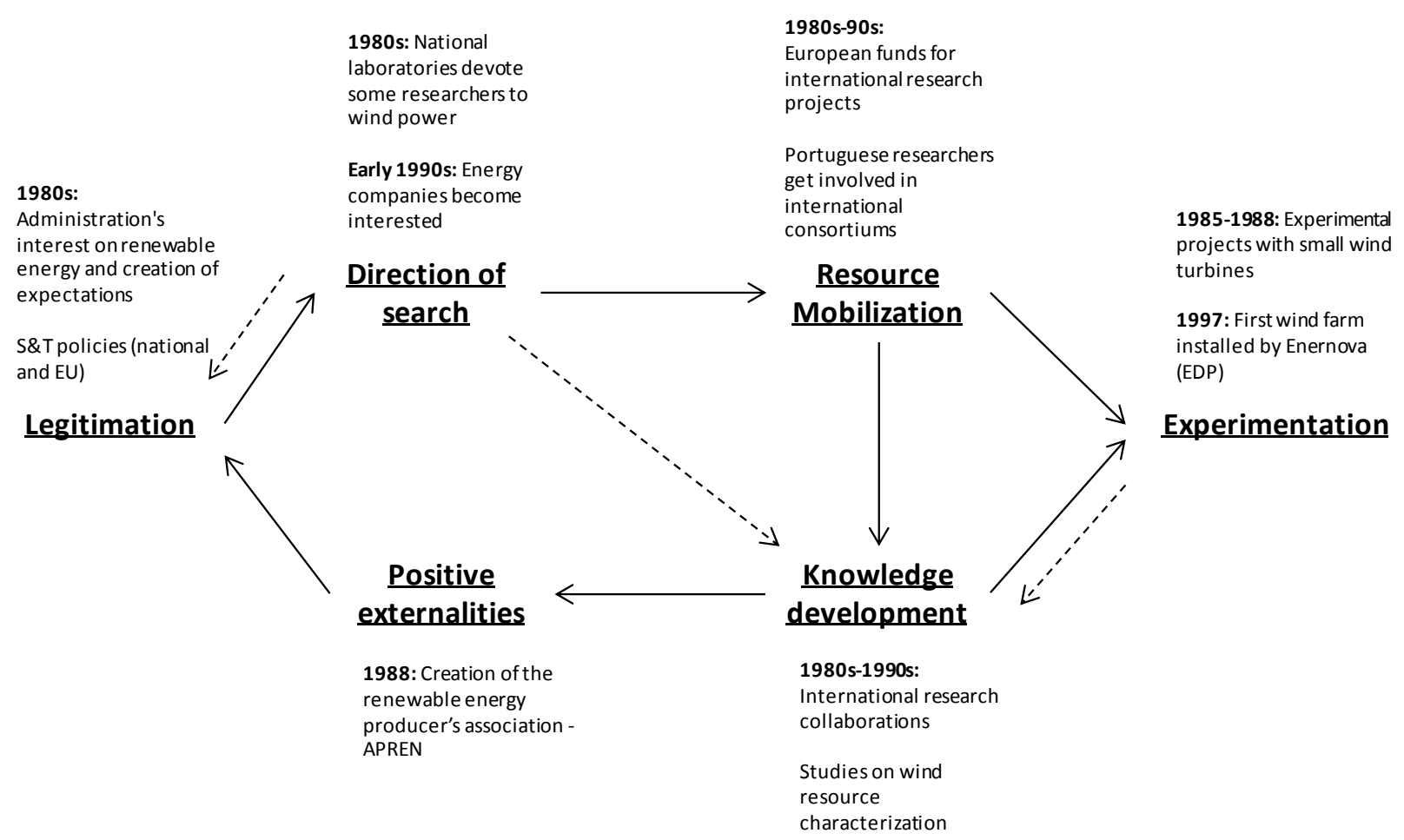

The exploratory stage was triggered by conventional science and technology policies, both at national and European levels (Figure 6). On the one hand, the government's interest in renewable energies after the oil shocks created "expectations" (Borup et al., 2006) about the development of alternatives that influenced the direction of search. On the other hand, the country joins the European Community in 1986, at the moment when EC programs start providing resources for R\&D and demonstration projects on wind energy, beginning to displace nationally funded projects (Hendry and Harborne, 2011). Portuguese researchers, mainly from national laboratories and universities, get involved in international projects on the physical mapping of wind profiles and resources, already in the 1980s. This contributed to increase the productivity of wind farms, as well as to form local knowledge on wind modeling and wind technologies (Matos, 2013). At the same time, the experimentation with several imported small wind turbines generated 
applied knowledge that was helpful in the installation of the first wind farm in 1997 (Castro 2011). ${ }^{8}$ In fact, although this (and subsequent) wind farms used imported turbine technology, their efficient implementation relied on the competences already developed by the local actors. The good results from the first trials reinforced the credibility of wind as an alternative to incumbent technologies. Meanwhile, a community of actors was formed that contributed to further legitimatize wind power and disseminate the belief in its growth potential. The creation of the renewable energy producers' association (APREN) in 1988 was the key point in the emergence of an advocacy coalition (IRENA-GWEC, 2012). This had many positive externalities for the development of the TIS, in particular for the implementation of wind support schemes.

\section{Figure 7. Implementation stage of wind energy in Portugal}

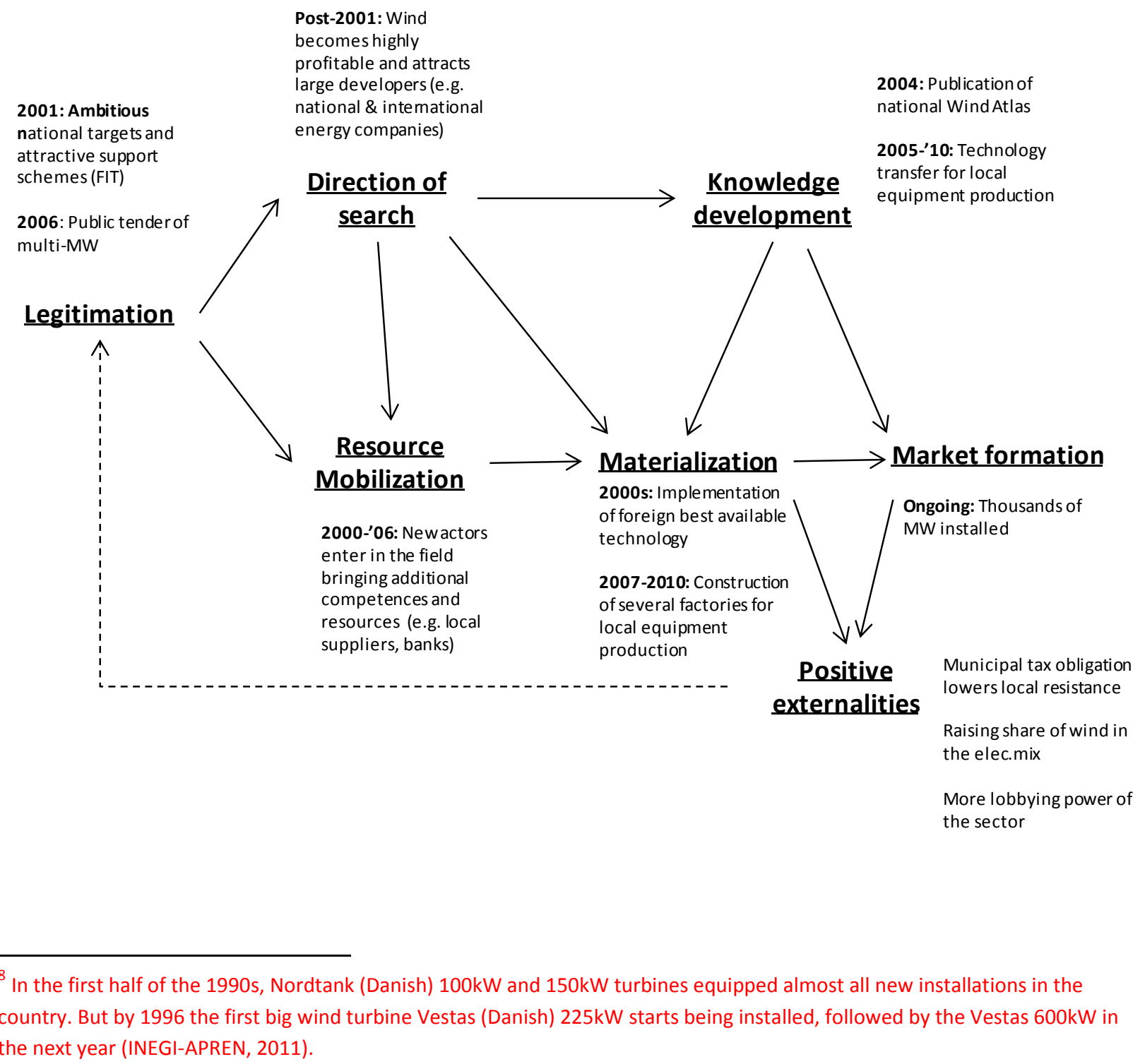



development of commercially viable multi-MW turbines and their successful market diffusion in Denmark, Spain and Germany, had set a favorable context for wind energy growth (Neij and Andersen, 2012). The obligations imposed by the European Directive on Renewable Energies opened a "window of opportunity" to invest in wind energy. These factors worked together to legitimatize wind energy and helped to align institutions to the requirements of the emerging innovation system. The setting-up of a new feed-in tariff, in 2001, influenced the direction of search of the main actors, starting with the energy utility. It also attracted new investors (e.g., private financers, financial institutions, engineering and electrical equipment companies), who brought more resources to the TIS, in the form of capital or complementary knowledge. The feed-in tariff was important for the development of wind energy in Portugal, as it enabled hard market formation. During the next years, total installed capacity jumped from dozens to thousands MW. Good remuneration of production and high land costs contributed to the adoption of large, imported multi-MW turbines (IEA, 2003). Later, the attribution of licenses for new installations was organized around public tenders, tied with local production obligations (Martins et al., 2011). This measure brought a series of investments in the emerging "wind cluster", through the establishment of joint-ventures between the energy utility, engineering companies and international equipment manufacturers. ${ }^{9}$ These investments materialized in several factories of blades, towers and turbines to equip the new wind farms. The difficulties faced to finance the implementation of the new wind farms led exports of wind power plants to start earlier than expected (by the forecasted saturation of the internal market).

In contrast with the strategy followed in the previous phase, which mainly opted for the direct acquisition of equipment to international manufacturers, like the established Danish producers, the strategy in the implementation phase was focused on building-up a local industry. This combined the attraction of foreign direct investment by manufacturers of the core technologies (i.e. turbines), with the continued development of competences, among local companies, in the production of additional components, as well as in the activities required to install, operate and maintain the wind power plants.

This reinforced the positive public perceptions concerning wind power (Delicado et al., 2013). In fact, resistance to the installation of turbines is globally low, mainly thanks to an additional requirement that obliges wind energy producers to pay $2.5 \%$ of the revenues to local municipalities. As more and more capacity is added and the best sites onshore are exploited, the focus of the research starts to shift towards the development of the offshore potential (IEA, 2012). Though, more recently, the financial crisis raised questions about the legitimacy of the rents in the sector, and producers are nowadays actively involved in lobbying to preserve their benefits.

Hence, the development of wind energy in Portugal reveals two virtuous cycles, characterized by a positive dynamic relationship between system functions (also described as "motor of changes", cf. Hekkert et al. (2007) and Suurs and Hekkert (2009)) that pulled other functions and created momentum in the growth of the innovation system: a knowledge development cycle and an implementation cycle.

\footnotetext{
${ }^{9}$ Even though some weakness can be pointed to the tendering system such as complexity that may hinder the participation of smaller and medium developers or lack of transparency in the formulation of the calls or in the choice of the winner bids. See: Friebe et al., 2014.
} 


\subsection{Integrating the international dimension in the emergence of the national TIS}

The evidence on spatial acceleration of wind diffusion raises an important question about the main processes that contributed to intensify the growth of the Portuguese wind TIS, as the technology got out of the core and reached the new market. The analysis conducted in the previous section provides some evidence that, as suggested by the (catching-up) literature, this phenomenon has not only internal but also external causes, which are connected with the context where the innovation takes place.

The presence of external knowledge spillovers from the diffusion in the core may be a major driver for growth acceleration in the subsequent markets. Technology starts to penetrate into new markets when it becomes more mature and a significant part of the learning investments have already been supported by the pioneer markets (Nemet, 2009). Other regions benefit from knowledge and technology spillovers created during the early innovation stages in the lead countries (Jaffe, 2005; Perkins and Neumayer, 2005). In fact, wind power only takes off in Portugal in the beginning of the years 2000s, when turbines had already scaled up and diffusion is well into the growth phase in the core (See Section 4.2). That said, the effective implementation of the imported technology always requires the recipient country to have some internal technological, as well as institutional, capacity to absorb and assimilate the new technologies (Mowery and Oxley, 1995; Teixeira and Fortuna, 2010; Criscuolo and Narula, 2008). In the case of the adoption of wind power in Portugal, the creation and reinforcement of the absorptive capacity took mainly three forms.

Firstly, the participation in international $R \& D$ projects contributed for the formation of knowledge in the early years, enabling a more rapid technology transfer and growth of wind power. The participation of national research laboratories in European projects since the 1980s was decisive to form a local knowledge base on wind modeling and evaluation, which proved useful later on, when the market took off. In fact, the implementation of wind parks has unfolded almost without the need to hiring any international consultants (Matos, 2013; Estanqueiro, 2013). The Portuguese case corroborates the theory which suggests that by conducting basic R\&D activities, organizations (and ultimately countries) can 
improve both the rate of technology transfer and the effectiveness in its use (Fabrizio, 2009; Cappelli et al., 2014).

Secondly, the development of the value chain was important to support the implementation of the technology. It drew on local engineering and industrial competences in non core technologies (i.e., beyond wind turbines) such as tower technologies and electrical components, as in other fast follower countries (Lund, 2009). In fact, the emergence of the wind innovation system benefited from available knowledge on hydroelectric power, and from the conversion into wind of activities from declining sectors (e.g., metalomechanics, construction). This is similar to what had previously happened in Denmark, when local firms sought, in the emerging wind cluster, the opportunity to diversify the activities from their declining business (Karnøe and Garud, 2012). Consequently, national incorporation was relatively high since the beginning. Almost all towers, as well as transformers and other electrical equipment, were built in Portugal, by local firms (Wind Directions, 2004). The sharing of elements with other innovation systems enlarged the knowledge and resources at the disposal of the new innovation system, contributing to raise the social consensus around wind power (Geels, 2005). Yet, in contrast to the more "distributed" experience of Denmark (Karnøe and Garud, 2012), the main energy utility has played a central role in the development of wind energy in Portugal since the beginning, affording increased legitimacy and lobbying power.

Thirdly, the establishment of strategic alliances with foreign companies allowed to overcome weaknesses in indigenous technical capacity regarding the core technologies, as well as to foster knowledge transfer (Mowery et al., 1996; Lewis and Wiser, 2007). The joint ventures established between international turbine manufacturers, such as Enercon and REpower, and local promoters led to the installation of manufacturing subsidiaries in the country, enabling the (timely) access to state-of-the-art technology and the creation of a local industrial cluster. ${ }^{10}$ These alliances were established to answer to the public tender organized in 2005, which required the bidders to produce locally equipment for wind farms, in exchange for the right to connect new capacity and to receive the regulated tariff (Martins et al., 2011). The tendering process provided enough stability and perspectives of domestic market growth to encourage global actors to delocalize full turbine manufacturing plants (Lewis and Wiser, 2007; Jenner et al., 2012). Therefore this scheme was successful in creating collective resources and ensuring that some benefits (i.e. value-added creation, jobs) reverted to the country.

All in all, the story of the development of wind power in Portugal points to the importance of transnational contacts for technology transfer, as well as to the need of stimulating the local capacity to capture knowledge spillovers in order to rapidly implement the new technology. The interactions established with the global TIS clearly helped to fulfill the system functions and to accelerate the emergence of the local innovation system. Table 2 presents a synthesis of several events, comprising both domestic and transnational activities, which were decisive for the fulfillment of the core activities or functions.

\footnotetext{
${ }^{10}$ Lewis (2011) examines the case of development of the wind industry in China, India and South Korea, whose strategy for technology transfer arguably took the form of licensing and mergers and acquisitions of companies from the core of innovation. This opened the access to technological know-how that enabled these countries to play an important role when the market became increasingly globalized.
} 

capture knowledge spillovers through the fulfillment of functions of the innovation system (FIS)

\begin{tabular}{|c|c|c|c|c|c|c|c|c|}
\hline Event / FIS & 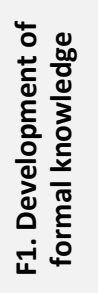 & 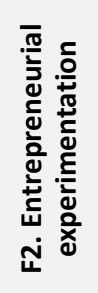 & 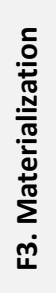 & 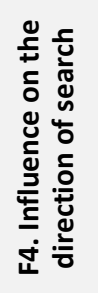 & 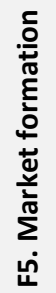 & 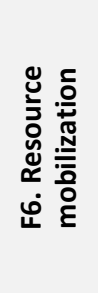 & 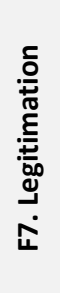 & 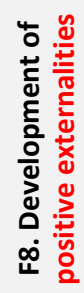 \\
\hline $\begin{array}{cl}\text { Domestic activities (increasi } \\
- & \text { national R\&D } \\
- & \text { development of } \\
& \text { local value chain } \\
- & \text { support schemes }\end{array}$ & ebsorpti & $\begin{array}{c}\text { acity) } \\
\bullet \\
\bullet\end{array}$ & $\begin{array}{l}\bullet \\
\bullet\end{array}$ & $\begin{array}{l}\bullet \\
\bullet \\
\bullet\end{array}$ & $\bullet$ & $\bullet$ & $\begin{array}{l}\bullet \\
\bullet \\
\bullet\end{array}$ & • \\
\hline $\begin{array}{cl}\text { Transnational activities (cap } \\
-\quad & \text { international } \\
& \text { R\&D projects } \\
-\quad & \text { strategic alliances } \\
& \text { with foreign } \\
& \text { companies } \\
\end{array}$ & ig know & $\begin{array}{c}\text { spillove } \\
\bullet \\
\bullet\end{array}$ & $\bullet$ & $\bullet$ & $\bullet$ & $\bullet$ & $\bullet$ & $\bullet$ \\
\hline
\end{tabular}

\section{Conclusions}

The international diffusion of energy technologies and the formation of technological capabilities in the receiving country were studied through the comparison of the growth of wind energy in Denmark (core) and in Portugal (fast follower). The very short delay with which wind technologies were adopted in Portugal relatively to the core and the scope of market penetration make this an interesting case of study, permitting to highlight the factors that can contribute to a rapid spatial diffusion.

The research drew on the empirical historical scaling dynamics to compare patterns of diffusion, and proposed an explanation for the patterns identified with the help of the technological innovation systems approach, in particular recent conceptualizations that attempt to (re)introduce the spatial dimension. Special attention was given to the factors that resulted from the interactions between an emerging country innovation system and the global TIS, which allowed the fulfillment of the key innovative processes.

A couple of lessons can be drawn from this case, which may contribute for technology policy design elsewhere - even though the efficacy of policies may change depending on the country and the timing. The central one is that the development of wind power took advantage of the assimilation of knowledge spillovers from abroad, through an improved local absorptive capacity. On the one hand, the diffusion of wind power benefited from the available competences in engineering and industrial activities. The formation of local knowledge was also possible thanks to the initial science and technology policy that permitted to build a knowledge base in the field and contributed, at the same time, to raise confidence in 


\section{Acknowledgments}

We gratefully acknowledge the funding of this research by the FCT (Fundação para a Ciência e a Tecnologia) through the research grant Ref $^{a}$ SFRH/BPD/91183/2012 and the research project Ref ${ }^{a}$ PTDC/CS-ECS/113568/2009. The authors would like to thank Ana Estanqueiro, José Carlos Matos, Alexandre Kisslinger, Rui Castro, Vítor Marques, Sergio Faias, Arnulf Grubler and Charlie Wilson as well as the participants of the 4th International Conference on Sustainability Transitions, in Zurich, and two anonymous referees. The usual disclaimer applies.

\section{References}

Bento, N., 2013. New Evidences in Technology Scaling Dynamics and the Role of the Formative Phase. International Institute for Applied Systems Analysis, IIASA Interim Report 13-004, Laxenburg, Austria.

Bento, N., Fontes, M., 2013a. A capacidade de adopção das inovações energéticas em Portugal: Evidência histórica e perspectivas para o futuro. Proceedings of the XV Latin Ibero-American Conference on Management of Technology - ALTEC 2013, Outubro 29-31, Oporto. 
Bento, N., Fontes, M., 2013b. Mechanisms that accelerate the diffusion of renewable technologies in new markets: Insights from the wind industry in Portugal. DINÂMIA'CET, Working paper n. ${ }^{\circ} 11 / 2013$, Lisbon.

Bergek, A., \& Jacobsson, S., 2003. The emergence of a growth industry: a comparative analysis of the German, Dutch and Swedish wind turbine industries. In: Change, Transformation and Development, Physica-Verlag HD, pp. 197-227.

Bergek, A., Jacobsson, S., Carisson, B., Lindmark, S., Rickne, A., 2008a. Analyzing the functional dynamics of technological innovation systems: A scheme of analysis. Research Policy 37(3), 407-407.

Bergek, A., Jacobsson, S., Sandén, B.A., 2008b. 'Legitimation' and 'development of positive externalities': two key processes in the formation phase of technological innovation systems. Technology Analysis \& Strategic Management, 20(5), 575-592.

Beurskens, L.W.M., Hekkenberg, M., Vethman, P., 2013. Renewable Energy Projections as Published in the National Renewable Energy Action Plans of the European Member States. HTML Spreadsheet, Energy research Centre of the Netherlands (ECN), Report ECN-E--10-069, 28 November 2011, Available at http://www.ecn.nl/nreap>.

Binz, C., Truffer, B., Coenen, L., 2014. Why space matters in technological innovation systemsMapping global knowledge dynamics of membrane bioreactor technology. Research Policy, 43(1), 138155.

Binz, C., Truffer, B., Li, L., Shi, Y., Lu, Y., 2012. Conceptualizing leapfrogging with spatially coupled innovation systems: The case of onsite wastewater treatment in China. Technological Forecasting \& Social Change 79, 155-171.

Bolinger, M., Wiser, R., 2012. Understanding wind turbine price trends in the US over the past decade. Energy Policy 42, 628-641.

Borup, M., Brown, N., Konrad, K., Van Lente, H., 2006. The sociology of expectations in science and technology, Technology Analysis \& Strategic Management, 18, 285-98.

BP 2013. BP Statistical Review of World Energy 2013. Available online at <www.bp.com/statisticalreview> (last accessed 8/7/2013).

Cappelli, R., Czarnitzki, D., Kraft, K., 2014. Sources of spillovers for imitation and innovation. Research Policy 43(1), 115-120.

Caragliu, A., Nijkamp, P, 2012. The impact of regional absorptive capacity on spatial knowledge spillovers: the Cohen and Levinthal model revisited. Applied Economics 44, 1363-1374.

Carlsson, B., Stankiewicz, R., 1991. On the nature, function and composition of technological systems. Journal of Evolutionary Economics 1(2), 93-118. 

Superior Técnico da Universidade Técnica de Lisboa, $1^{\text {a }}$ Edição.

Coenen, L., Benneworth, P., Truffer, B., 2012. Toward a spatial perspective on sustainability transitions. Research Policy 41(6), 968-979.

Cohen, M.W., Levinthal, D.A., 1989. Innovation and learning: The two faces of R\&D. Economic Journal 99, 569-596.

Cohen, W.M., Levinthal, D.A., 1990. Absorptive Capacity: A New Perspective on Learning and Innovation. Administrative Science Quarterly 35(1), 128-152.

Criscuolo, P., Narula, R., 2008. A novel approach to national technological accumulation and absorptive capacity: Aggregating Cohen and Levinthal. The European Journal of Development Research 20(1), 5673.

Danish Energy Agency 2013. Annual Energy Statistics. HTML-spreadsheet, Available at $<$ http://www.ens.dk/en/info/facts-figures/energy-statistics-indicators-energy-efficiency/annual-energystatistics> (Last accessed in August 2013).

Delicado, A., Silva, L., Junqueira, L., Horta, A., Fonseca, S., Truninger, M., 2013. Ambiente, paisagem, património e economia: Os conflitos em torno de parques eólicos em Portugal. Revista Crítica de Ciências Sociais, (100), 11-36.

DGEG 2013. Renováveis: Estatísticas Rápidas - junho 2013. Direcção Geral de Energia e Geologia, available at <http://www.dgeg.pt/>, Lisboa.

Ebers, M., Maurer, I., 2014. Connections count: How relational embeddedness and relational empowerment foster absorptive capacity. Research Policy 43(2), 318-332.

Edquist, C., Johnson, B., 1997. Institutions and organizations in systems of innovation, in: Edquist, C. (Ed.), Systems of Innovation: Technologies, Institutions and Organizations. Pinter Publishers, London, pp. 41-63.

Estanqueiro, A., 2013. Interview with Ana Estanqueiro. Laboratório Nacional de Energia e Geologia, LNEG, Lisboa, May 23.

EurObserv'ER (2013), The State of Renewable Energies in Europe - 2013 Edition, Paris.

EWEA 2013. Wind in Power: 2012 European statistics. The European Wind Energy Association, February, www.ewea.org.

Fabrizio, K., 2009. Absorptive capacity and the search for innovation. Research Policy 38, 255-267.

Fagerberg, J., Godinho, M.M., 2005. Innovation and catching-up, in: Fagerberg, J., Mowery, D., Nelson, R. (Eds.), The Oxford Handbook of Innovation. Oxford University Press, New York, pp. 514-543. 

markets-the role of public policy for wind energy. Energy Policy, 70, 217-226.

Garud, R., Karnøe, P., 2003. Bricolage versus breakthrough: distributed and embedded agency in technology entrepreneurship. Research policy 32(2), 277-300.

Geels, F., 2005. Processes and patterns in transitions and system innovations: Refining the co-evolutionary multi-level perspective. Technological Forecasting \& Social Change 72, 681-696.

Gipe P., 1995. Wind Energy Comes of Age, John Wiley and Sons Inc.

Gosens, J., Lu, Y., \& Coenen, L., 2013. Clean-tech innovation in emerging economies: transnational dimensions in technological innovation system formation. Technological Forecasting \& Social Change (submitted for publication).

Grubler, A., 1998. Technology and Global Change. Cambridge University Press, Cambridge, UK.

Grubler, A., 2012. Energy transitions research: Insights and cautionary tales. Energy Policy 50, 8-16.

GWEC 2013. Global Wind Report - Annual market update 2012. Global Wind Energy Council, Brussels.

Hekkert, M.P., Negro, S.O., 2009. Functions of innovation systems as a framework to understand sustainable technological change: Empirical evidence for earlier claims. Technological Forecasting \& Social Change 76(4), 584-594.

Hekkert, M.P., Suurs, R.A.A., Negro, S.O., Kuhlmann, S., Smits, R., 2007. Functions of Innovation Systems: A new approach for analysing technological change. Technological Forecasting \& Social Change 74(4), 413-432.

Hekkert, M.P., Negro, S.O., Harmsen, R., Heimeriks, G.J., 2011. Technological innovation system analysis: a manual for analysts. Utrecht University, Report for Joint Research Center, Energy Institute.

Hendry, C., Harborne, P., 2011. Changing the view of wind power development: More than "bricolage". Research Policy 40(5), 778-789.

IEA 2003. IEA Wind 2003 Annual Report - Chapter 16: Portugal. IEA/OECD, Paris.

IEA 2004. IEA Wind 2004 Annual Report - Chapter 18: Portugal. IEA/OECD, Paris.

IEA 2009. IEA Wind 2009 Annual Report - Chapter 25: Portugal. IEA/OECD, Paris.

IEA 2012. IEA Wind 2011 Annual Report - Chapter 29: Portugal. IEA/OECD, Paris.

INEGI/APREN (2011), Parques Eólicos em Portugal, December 2011, e2p, Available at <http://e2p.inegi.up.pt/relatorios/Portugal_Parques_Eolicos_201112.pdf> (last accessed January 3, 2013).

IPCC 2014. Climate Change 2014: Mitigation of Climate Change. Working Group III Contribution to the Fifth Assessment Report (WGIII AR5), United Nations Intergovernmental Panel on Climate Change, Stockholm, 23-26 September 2013, Available at < http://mitigation2014.org>. 
IRENA-GWEC 2012. 30 Years of Policies for Wind Energy: Lessons from 12 Wind Energy Markets. Global Wind Energy Council and International Renewable Energy Agency, Abu Dhabi.

Jacobsson, S., Bergek, A., 2004. Transforming the energy sector: the evolution of technological systems in renewable energy technology. Industrial and Corporate Change 13, 815-849.

Jacobsson, S., Bergek, A., 2012. Innovation system analyses and sustainability transitions: Contributions and suggestions for research. Survey, Environmental Innovation and Societal Transitions 1, 41-57.

Jacobsson, S., Johnson, A., 2000. The diffusion of renewable energy technology: an analytical framework and key issues for research. Energy Policy 28, 625-640.

Jaffe, A.B., 2005. The Importance of "Spillovers" in the Policy Mission of the Advanced Technology Program. Advanced Technology Program, National Institute of Standards and Technology, http://www.atp.nist.gov/eao/jtt/jaffe.htm (last accessed August 5, 2013).

Jenner, S., Groba, F., Indvik, J., 2012. Assessing the strength and effectiveness of renewable electricity feed-in tariffs in European Union countries. Energy Policy 52, 385-401.

Kamp, L. M. (2008). Socio-technical analysis of the introduction of wind power in the Netherlands and Denmark. International Journal of Environmental Technology and Management 9(2), 276-293.

Kamp, L.M., Smits, R.E., Andriesse, C.D., 2004. Notions on learning applied to wind turbine development in the Netherlands and Denmark. Energy policy 32(14), 1625-1637.

Karnøe, P., Garud, R., 2012. Path creation: Co-creation of heterogeneous resources in the emergence of the Danish wind turbine cluster. European Planning Studies 20(5), 733-752.

Keller, W., 2010. International Trade, Foreign Direct Investment, and Technology Spillovers, in: Hall, B., Rosenberg, N., (Eds.), Handbook of the Economics of Innovation, Chapter 19, Elsevier North-Holland, pp.793-829.

Lane, P.J., Koka, B.R., Pathak, S., 2006. The reification of absorptive capacity: a critical review and rejuvenation of the construct. Academy of management review 31(4), 833-863.

Lee, G.K., 2009. Understanding the timing of 'fast-second'entry and the relevance of capabilities in invention vs. commercialization. Research Policy 38(1), 86-95.

Lewis, J.I. (2011). Building a national wind turbine industry: experiences from China, India and South Korea. International Journal of Technology and Globalisation 5 (3/4): 281-305.

Lewis, J.I., Wiser, R.H., 2007. Fostering a renewable energy technology industry: An international comparison of wind industry policy support mechanisms. Energy policy 35, 1844-1857.

Lund, P.D., 2009. Effects of energy policies on industry expansion in renewable energy. Renewable Energy 34(1), 53-64. 
Marchetti, C., Nakicenovic, N., 1979. The dynamics of energy systems and the logistic substitution model. IIASA Research Report RR-79-013, Laxenburg, Austria.

Markard, J., Musiolik, J., Worch, H., 2011. Development of system resources in an emerging technological field: on the role of organizations and formal networks. In: Paper presented at the DIME Final Conference, April (Vol. 6, p. 8).

Markard, J., Raven, R., Truffer, B., 2012. Sustainability transitions: An emerging field of research and its prospects. Research Policy 41(6), 955-967.

Markard, J., \& Truffer, B., 2008. Technological innovation systems and the multi-level perspective:

Towards an integrated framework. Research Policy 37(4), 596-615.

Markides, C., Geroski, P., 2005. Fast second. Jossey-Bass, San Francisco.

Martins, A.C., Marques, R.C., Cruz, C.O., 2011. Public-private partnerships for wind power generation: The Portuguese case. Energy Policy 39(1), 94-104.

Matos, J.C., 2013. Interview with Eng. ${ }^{\circ}$ José Carlos Matos, Wind Energy Group, Institute of mechanical engineering and industrial management, INEGI, Porto, May 17.

McDowall, W., Ekins, P., Radošević, S., Zhang, L.Y., 2013. The development of wind power in China, Europe and the USA: how have policies and innovation system activities co-evolved?. Technology Analysis \& Strategic Management 25(2), 163-185.

Mowery, D., Oxley, J., 1995. Inward technology transfer and competitiveness: the role of national innovation systems. Cambridge Journal of Economics 19 (1), 67-93.

Mowery, D.C., Oxley, J.E., Silverman, B.S., 1996. Strategic alliances and interfirm knowledge transfer. Strategic management journal 17, 77-91.

Narula, R., 2004. Understanding absorptive capacities in an "innovation systems" context: consequences for economic and employment growth. DRUID Working Papers 04-02, <http://www3.druid.dk/wp/20040002.pdf>.

Neij, L., Andersen, P.D., 2012. A Comparative Assessment of Wind Turbine Innovation and Diffusion Policies. Historical Case Studies of Energy Technology Innovation, in: Chapter 24, The Global Energy Assessment, Grubler, A., Aguayo, F., Gallagher, K.S., Hekkert, M., Jiang, K., Mytelka, L., Neij, L., Nemet, G., C., Wilson. Cambridge University Press: Cambridge, UK.

Nemet, G.F., 2009. Demand-pull, technology-push, and government-led incentives for non-incremental technical change. Research Policy 38, 700-709.

North, D.C., 1990. Institutions, Institutional Change and Economic Performance. Cambridge University Press. 

analysis of latecomer advantage and global economic integration. Annals of the Association of American Geographers 95(4), 789-808.

Peña, I., 2013. Economic analysis on the profitability of wind in Portugal between 1992-2010. International Energy Workshop (IEW), Paris, June 19-21st.

Público 2011. Renováveis não são exclusivo de um governo, vêm de há três décadas - Entrevista com Aníbal Fernandes. Público Económia 02/12/2011.

Rogers E.M., 1995. Diffusion of Innovations. 4th edition, New York: Simon and Schuster.

Spliid, I., 2013. Stamdataregister for vindmøller. HTML-spreadsheet, Danish Energy Agency, Available at $\quad<\mathrm{http}: / / \mathrm{www} . e n s . d k /$ info/tal-kort/statistik-noegletal/oversigt-energisektoren/stamdataregistervindmoller> (Last accessed: 23 April).

Suurs, R.A.A., Hekkert, M.P., 2009. Motors of Sustainable Innovation. Towards a Theory on the Dynamics of Technological Innovation Systems. Thesis, Utrecht University, Utrecht.

Teixeira, A.A., Fortuna, N., 2010. Human capital, R\&D, trade, and long-run productivity. Testing the technological absorption hypothesis for the Portuguese economy, 1960-2001. Research Policy 39(3), 335350.

Todorova, G., Durisin, B., 2007. Absorptive capacity: Valuing a reconceptualization. Academy of Management Review 32(3), 774-786.

Van Alphen, K. 2011. Accelerating the development and deployment of carbon capture and storage technologies : an innovation system perspective. $\mathrm{PhD}$, Utrecht University.

Vasseur, V., Kamp, L.M., \& Negro, S.O., 2013. A comparative analysis of Photovoltaic Technological Innovation Systems including international dimensions: the cases of Japan and The Netherlands. Journal of Cleaner Production, 48, 200-210.

Volberda, H.W., Foss, N.J., Lyles, M.A., 2010. Absorbing the concept of absorptive capacity: how to realize its potential in the organization field. Organization Science 21, 931-951.

Wieczorek, A., Raven, R., Berkhout, F., 2013. Transnational linkages in sustainability experiments of India, In: Paper presented at International Sustainability Transition Conference, Zurich, June.

Wilson, C., 2009. Meta-analysis of unit and industry level scaling dynamics in energy technologies and climate change mitigation scenarios. IIASA Interim Report IR-09-029, Laxenburg, Austria.

Wilson, C., 2012. Up-Scaling, Formative Phases, and Learning in the Historical Diffusion of Energy Technologies. Energy Policy 50, 81-94.

Wilson, C., Grubler, A., 2011. Lessons from the history of technological change for clean energy scenarios and policies. Natural Resources Forum 35, 165-184. 
Wind Directions 2004. New Team in the European Wind League. Focus on Portugal. Wind Directions, July/August.

Zahra, S.A., George, G., 2002. Absorptive Capacity: A Review, Reconceptualization, and Extension. The Academy of Management Review 27(2), 185-203. 